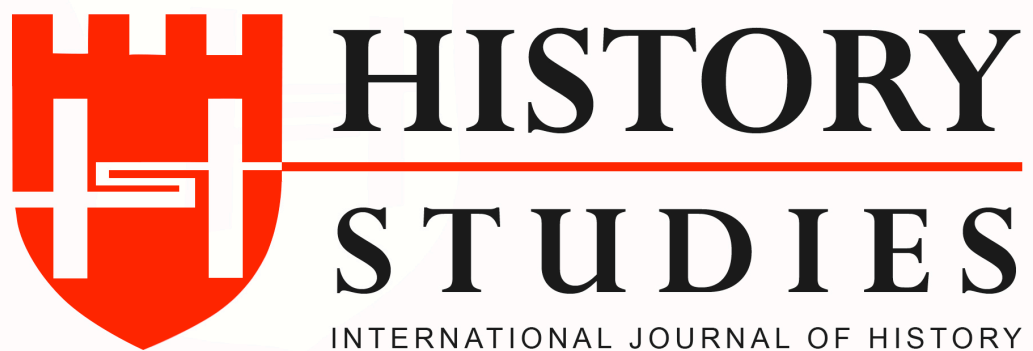

ISSN: 13094173 (Online) 1309 - 4688 (Print)

Volume 12 Issue 1, February 2020

DOI Number: 10.9737/hist.2020.819

Araştırma Makalesi

Makalenin Geliş Tarihi: 04.11.2019 Kabul Tarihi: 30.01.2020

Atıf Künyesi: Şevket Ayyıldız, "Cultural Change in Central Asia: Brezhnev, Modern Sports, and Memories in Uzbekistan, 1964 to 1982", History Studies, 12/1, Şubat 2020, s. 35-54.

\title{
Cultural Change in Central Asia: Brezhnev, Modern Sports, and Memories in Uzbekistan, 1964 to 1982
}

\author{
Dr. Şevket Ayyıldız \\ ORCID No: 0000-0001-9545-4432 \\ SOAS, University of London
}

\begin{abstract}
The Cold War Soviet leaders Nikita Khrushchev (d. 1971) and Leonid Brezhnev (d. 1982), between 1953 and 1982, continued with Vladimir Lenin's (d. 1924) and Joseph Stalin's (d. 1953) physical culture policy designed to create healthier citizen-workers and soldiers. The underlining concept was to construct a communist society. In the process, the Soviet culture and sports culture played a role in integrating the different ethnic groups into the multinational Soviet Union. Leonid Brezhnev (Communist Party leader from 1964 to 1982) consolidated and expanded the Soviet sports system, albeit in a changing historical context. Our paper, firstly, describes the concept of Soviet modernity and physical culture. Secondly, in the context of Brezhnev's tenure, we investigate the development of the modern sports infrastructure in Tashkent, and the numerical growth of the ordinary and the elite sportspeople in Uzbekistan. Thirdly, to explain what this meant to the everyday Central Asian, we have incorporated their oral histories into our study. This inclusion of the people's memories will provide us with a bottom-up perspective of Soviet sport, and enrich our understanding of the ordinary citizen's relationship with the Soviet Union's sports culture.
\end{abstract}

Keywords: Brezhnev, Central Asia, physical culture, Soviet Union, sport, Uzbekistan

\section{Introduction}

After the 1917 Russian Revolution and the Civil War (1917 to 1922), Lenin pushed ahead with the modernisation of the Russian and Central Asian societies. Alongside the plans for social transformation, industrialisation, and urbanisation, was the intention to create an egalitarian and meritocratic society. The social engineering used by the Communist Party exposed the citizenry to the Soviet culture, arts, and sports. Lenin chose to use the statecontrolled physical culture to create healthier soldiers and industrious workers and to promote 'human emancipation'. However, Stalin, from the late 1920s onwards, took the socialist revolution in an authoritarian direction. He governed the Central Asian periphery from the European metropolis of Moscow. In this top-down model of power and control, the monolithic one-party system encouraged patriotic and self-disciplined politicians, cadres, and managers. Indeed, what happened regionally and locally relied upon willing communist elites and compliant and indoctrinated citizens. The Soviet Union's 15 national republics and the ruralurban divide complicated the economic development and management of society. In this context, modern sports were used to integrate and acculturate the citizenry.

\section{History Studies}


Our paper is an interdisciplinary area study that will investigate modern sports in the Central Asian republic of Uzbekistan. We discuss how the Brezhnev regime continued with Stalin's and Khrushchev's policies to turn the republic's citizens into active sportspeople. The focus of our study addresses the development of urban-based sports - and the recollections of the oral histories of young people. By looking at the Brezhnev period between (October) 1964 and (November) 1982, we are exploring the post-Stalinist era of Soviet culture and sport; it was a period 45 years after the 1917 Revolution. The Soviet sport from 1953 and 1982 operated in a different historical context. However, as we will show, in other ways, it was a continuation of sports policies established by Lenin and Stalin and further developed by Khrushchev (Communist Party leader from September 1953 to October 1964).

The late-Soviet sports culture and its role in the everyday lives of urban Central Asians have shaped our hypothesis. Our focus will explore the modern sports development in urban Uzbekistan under Brezhnev, and the responses of the Central Asians who experienced Soviet sport. Our three research questions will analyse (i) how developed was the modern sports-built environment, and what were the numbers of sportspeople involved? (ii) What was the situation of women and sport in Uzbekistan? (iii) How do Central Asians remember their Soviet sports past, especially their involvement with it?

Our paper concentrates upon modern sports; therefore, folk and traditional sports are only briefly addressed in our work. The reader should be aware that Stalin had the national folk sports standardised and incorporated into the new physical culture. Folk sports always remained popular in the rural Soviet Union because here the modern sports were less developed and traditional culture and local identity were vibrant in the home. The elite folk sports athletes were household names, and the most talented ones could achieve Soviet Master of Sport status. ${ }^{1}$

Uzbekistan is a noteworthy case study because it has the largest population in Central Asia, and Tashkent was once the fourth largest Soviet city (population nearly 1,780,000 in 1979). All through the 70 years of Communist Party rule, Uzbekistan's population was mainly rural and multicultural (approximately 70 per cent were ethnic Uzbek). After 1917, this conservative Muslim society was viewed by Moscow as a place of social experimentation, and the communists were keen to implement their control and acculturation policies. In this paper, we will show that Uzbekistan (and Kazakhstan) proved to be reasonably successful cases of sports development.

The primary sources used in our research stem from the ideological and political context of the Cold War. Brezhnev delivered the Report of the Central Committee of the CPSU to the XXVI Congress of the Communist Party on $23^{\text {rd }}$ February $1981 .^{2}$ This report was the Party's reaffirmation of its Marxist-Leninist aims and goals, acknowledgement of the progress achieved, and proposals for future planning. The Soviet documents available online through the Joint Publications Research Service (JPRS, Arlington, Virginia, United States) are English language translations of the Soviet newspapers and Communist Party publications. JPRS documents provide an insight into the state of socio-economic development in Central Asia from the Soviet perspective. We need to be cautious of the Soviet statistics in the primary and secondary sources on Central Asia because they might be false. Falsification happened because

\footnotetext{
${ }^{1}$ See Sevket Hylton Akyildiz, "Modern and Folk Sports in Central Asia under Lenin and Stalin: Uzbekistan from 1925 to 1952," Vakanuvis - International Journal of Historical Researches 4:2 (Fall 2019): 515-541; the author explains how the Central Asian folk sports were codified and institutionalised by the Soviet state planners.

${ }^{2}$ L.I. Brezhnev, Report of the Central Committee of the CPSU. (Moscow: Novosti Press Agency Publishing House, 1981), 81-2.
} 
local cadres wished to fulfil Moscow's planning quota, so the Soviet sources might not always be an accurate picture of events on the ground.

We conducted ten unstructured (in-depth) oral history interviews between 2011 and 2019 with former Soviet citizens now resident in the United Kingdom. Our expatriates originated from different social and ethnic Central Asian backgrounds; however, five of them hold Uzbekistan citizenship. A further ten unstructured interviews involved Uzbek citizens residing in Uzbekistan (these were part of our fieldwork notes of 2009). All of the 20 interviewees, now middle-aged or older, were young adults at the time of the late 1970s and early to mid-1980s. They were involved with modern sports at schools and colleges and some through the youth movements (the Young Pioneers for ages 10 to 14, established 1922, and the Komsomol for ages 15 to 28, established 1918). Their recollections are subjective; however, they provide us with eyewitness accounts. Our findings prove novel because we are not dealing with people and trauma and war (and forgetting). Instead, we are looking at their relationship with the Soviet popular culture. The individual and collective recollections refer back to the authoritarian regime's attempt to improve the citizenry's health and wellbeing. ${ }^{3}$ The interview questions we asked our eyewitnesses originated from one or two topics about the Soviet past and sport. In a generational and life-cycle context, the young adult years are significant in the development of personal identity and, with this in mind, we have attempted to understand how the communist leisure and sport helped shape their values, attitudes, and behaviour. We seek to clarify how they and their peer group interacted with the Soviet sports culture as athletes and spectators, and what it meant in their everyday lives. Orlando Figes calls this 'Soviet subjectivity': '... the degree to which the interior life of the individual citizen was dominated by the regime's ideology'. ${ }^{4}$ Our work adds to this analysis by highlighting the Central Asian's remembrance of Soviet culture and sport and how they related to the unionwide physical culture programme, societies and clubs. Despite the top-down imposition of Soviet policies, we looked for cases of non-compliance among the sporting respondents? (As we shall see, Respondent 3 shows an element of quiet resistance). Lastly, the individual responses reveal to us facts about their Soviet past, how they remember and perceive (culturally, politically and psychologically) the Soviet sport in both private and collective contexts, and what this means for them today. In discussing memory, Michael Richards says: ${ }^{5}$

First, memory reveals positive facts about past events and about the experience of those events, be they wars, revolutions, or everyday realities in times of normality. Second, and more important, it tells us how recollections of events are acquired and subsequently altered in the constant forming and re-forming of identities. Memory is shaped by our changing surroundings and the way we interpret them.

The secondary sources used in our research include Soviet, British, and United States books published during the Cold War era and contemporary European publications. The book Soviet Sport: The Success Story (1987) ${ }^{6}$ published in Moscow for a non-Soviet English-speaking audience, contains much information and data on Soviet sport. It makes numerous unsubstantiated claims about the development of Soviet sport by highlighting its accomplishments but fails to mention drug-taking, corruption, cheating, and the inadequate

\footnotetext{
${ }^{3}$ For analysis on trauma and war see Timur Dadabaev, "Trauma and Public Memory in Central Asia: Public responses to political violence of the state policies in Stalinist Era in Uzbekistan and Kyrgyzstan," Kyoto Bulletin of Islamic Area Studies 3:1 (July 2009): 108-138.

${ }^{4}$ Orlando Figes, The Whisperers: Private Life in Stalin's Russia. (London: Penguin, 2008), xxxiv.

${ }^{5}$ Michael Richards, "From war culture to civil society: Francoism, social change, and memories of the Spanish Civil War", History and Memory 14:1 Special Issue: Spanish Memories: Images of a Contested Past (2002): 93-120, 93.

${ }^{6}$ A. Timofeyev and Y. Kopytkin, Soviet Sport: The Success Story. (Moscow: Raduga Publishers, 1987).
} 
sports facilities in rural society. James Riordan's Sport in Soviet Society $(1980)^{7}$ is a comprehensive text that covers the historical period from about the mid-1800s to the late 1970s. Riordan has used his Soviet Union fieldwork notes, Soviet newspaper stories, and Soviet and Western literature. He explains the evolution of modern - and folk sports - in the Soviet Union with insightful and non-biased observations. Equally, his book Soviet Sport: Background to the Olympics $(1980)^{8}$ provides us with an introductory analysis of the world of Soviet sports during the Cold War. Riordan's journal articles are in this study. Other Western texts provide us with discussion on Soviet modernity and culture from different perspectives. For example, the Soviet-era Polish emigre Michael Rywkin (1990) ${ }^{9}$ critically focuses upon the colonial and authoritarian nature of the Soviet Union, while the Asian-British intellectual Shirin Akiner (1993) ${ }^{10}$ emphasises the complexity and nuances of the relationship between Moscow and Central Asia. The edited book Euphoria and Exhaustion: Modern Sport in Soviet Culture and Society by Nikolaus Katzer, Sandra Budy, Alexandra Kohring, and Manfred Zeller $(2010)^{11}$ is an excellent starting point for students and scholars to ascertain the current Western academic thinking on the Soviet culture and sports. Susan Grant's Physical Culture and Sport in Soviet Society: Propaganda, Acculturation, and Transformation in the in1920s and 1930s $(2013)^{12}$ is based upon archival research and contains a chapter devoted to the rural Soviet citizens and the non-Russian minorities.

In part one 'Soviet modernity and physical culture' we will define the concepts of Soviet 'modernity' and 'culture' and the relationship between Marxism-Leninism and physical culture and sport. In the section 'Sports policy: Khrushchev and Brezhnev' we summarise Khrushchev's sports developments in the Soviet Union, a period that followed the death of Stalin. Once we have clarified this historical background, we will then review Brezhnev's key sports policy reforms. In part two 'Uzbekistan: developments, sportspeople and everyday accounts' we investigate the development and growth of modern sports in urban Uzbekistan under Brezhnev. We assess the scope of urban sports sites in Tashkent circa 1964; the numerical growth of sportspeople (both the ordinary and the elite athletes) in rural and urban Uzbekistan; women and sport, and elite athletes and 'sport-for-all'.

\section{Soviet modernity and physical culture}

\section{Soviet modernity and culture}

The Soviet culture was a component of a broader ideological project known as 'Soviet modernity'. In the Soviet context, 'modernity' means the transformation of a patriarchal and outmoded social order into a scientific-atheist socialist society. Hence the religion and traditional culture, dynastic rule, rural life and agriculture, kin and regional communities are replaced with science, popular sovereignty, the nation-state and citizenship, factories and offices, and cities. The 'modernisation' processes involve rationalisation, industrialisation, and urbanisation. In Marxism-Leninism, this means the Communist Party would govern society (dictatorship of the proletariat) and guide the masses from the socialist revolution to the utopian

\footnotetext{
${ }^{7}$ James Riordan, Sport in Soviet Society: Development of Sport and Physical Education in Russia and the USSR. (Cambridge: Cambridge University Press, 1980).

${ }^{8}$ James Riordan, Soviet Sport: Background to the Olympics. (New York: Washington Mews Books, 1980).

${ }^{9}$ Michael Rywkin, Moscow's Muslim Challenge: Soviet Central Asia. (Armonk, New York: M. E. Sharpe, 1990).

${ }^{10}$ Shirin Akiner, Central Asia: New Arc of Crisis? (London: Whitehall Paper Series, 1993).

${ }^{11}$ Nikolaus Katzer and Sandra Budy and Alexandra Kohring and Manfred Zeller, Euphoria and Exhaustion: Modern Sport in Soviet Culture and Society (Frankfurt: CampusVerlag, 2010).

${ }^{12}$ Susan Grant, Physical Culture and Sport in Soviet Society: Propaganda, Acculturation, and Transformation in the 1920s and 1930s. (London: Routledge, 2013).
} 
society referred to as 'full or pure communism'. Under Stalin, this was implemented in a topdown bureaucratic manner by communist elites. During the transformation, the regime excluded the bourgeois class, religious people, or those with 'anti-Soviet' views; these socalled 'enemies of the people' fell victim to state terror.

In classical Marxism, culture is part of the superstructure and reflects the dominant ideology of a particular society. 'Soviet culture' was designed to integrate and help control the citizens regardless of their ethnicity or gender. The physical culture (incorporating sport) was part of Soviet culture. One core aim of the sports culture was to transmit Soviet values, attitudes, and identity across society. In the Soviet Union, sport always existed in a symbiotic relationship with modernisation, socialisation, indoctrination, and mass entertainment. The sports were a remedy to religion, drinking, prostitution, and antisocial behaviour. ${ }^{13}$ Stalin used the Cultural Revolution (1928 to 1931) to transform the cultures of the Soviet republics. In the case of Central Asia, the region exemplified the type of pre-industrial society that the communists wished to make modern. The Marxist-Leninist theory said that revolution was possible in an agricultural economy, and Central Asian communities were an example. Central Asia was viewed by Moscow as socially 'backwards', superstitious, and patriarchal; and therefore, a place to experiment with revolutionary socialism. The Soviet values and attitudes, universal literacy and education, costume and material life, intellectual and artistic works, and townplanning and architecture originated from Europeanised Russian high and popular cultures (referred to as Sovietisation). Russian became the official language (Russification). In constructing the Soviet people (Sovetski narod) over decades, the Soviet acculturation and nationalities policy were intended to 'bring together' (sblizhenie) and eventually 'merge' (sliyanie) the Soviet nations into one communistic civic society (full communism). National characteristics would remain. The Soviet culture was ideological; however, its application was adapted to suit practical considerations and generational change. In 1930s Central Asia, elements of the native culture (costume, architecture, and folk sport) were absorbed into the Sovietisation process. During Khrushchev's and Brezhnev's tenure, the consumer culture was buoyant in the Soviet Union and new architecture, fashions, and Western-style youth culture emerged.

\section{Marxism-Leninism and physical culture and sport}

Soviet physical culture writes Susan Grant 'covered a wide spectrum ranging from hygiene and health issues to sports, defence interests, labour concerns, leisure, education, and general cultural enlightenment'. ${ }^{14}$ From the Soviet perspective, physical culture consists of four necessary components: 'organised physical education, playful activities, active leisure pursuits and sport' ${ }^{15}$ The communist sports culture was part of a new urban lifestyle and also used for mass entertainment.

The 'physical culture' we are describing emerged in nineteenth-century Great Britain, Germany and Scandinavia and is linked with an industrial society, urbanisation, military training, and nationalism. It was intended to advance planned leisure and wellbeing and to create energetic citizens for work and soldiery. The components included diet and health, fitness routines, and public hygiene, and sport. After the 1917 Russian Revolution, the Communist Party leadership copied this European sports model and also took control of the

\footnotetext{
${ }^{13}$ Riordan, Sport in Soviet Society, 4.

${ }^{14}$ Grant, Physical Culture and Sport, 1.

${ }^{15}$ Riordan, Sport in Soviet Society, 4.
} 
imperial Russian sports and military-sports associations. Lenin and Stalin established the Soviet physical culture with specific aims in mind linked with the development of society. These aims shaped the sports policies of the 1920s and 1930s.

'Modern sport' in this paper means the sports' rules and codes, clubs and services, sportspeople and athletes, coaching and training staff, spectators and fans. In particular, we refer to modern aquatic sports, ball games, combat sports, equestrian sports, field and track sports, martial arts, racket sports, and snow sports. Riordan writes: 'Organised sport is regarded as a playful, competitive physical or mental activity, based on rules and norms, with the object of achieving a result. ${ }^{16}$

The first Soviet sports policies included -

- In 1931, The Ready for Labour and Defence programme (GTO) was established and managed by the GTO Council. The GTO was core to mass physical education in terms of standards, tests, and content. The GTO advanced mass participation, sports excellence, and elite athleticism.

- In 1935, the unionwide Sports Classification System, working in conjunction with the GTO, ranked the ordinary and elite athletes by their ability and skills (with the Master of Sport being the highest award).

- In 1936, the Committee on Physical Culture and Sport was established to organise and coordinate implementation across the Soviet Union.

Sports policy: Khrushchev and Brezhnev

This section will summarise the key sports policies in the period 1953 to 1982, and provide the reader with background information. It is not a full analysis of the events; instead, we aim to show the dynamism in the building and expansion of the Soviet sports system.

Nikita Khrushchev led an improving post-war economy and attempted to advance the material living for the Soviet family. His 'Secret Speech' in 1956 denounced Stalin's crimes. During the late 1950s and early 1960s, Khrushchev relaxed state repression and censorship (known as the Thaw). ${ }^{17}$ On the sports front, in 1956, the Soviet Union Olympic team came top of the medals table at the Winter Olympics in Italy and the Melbourne Summer Olympic Games. They came top at the 1960 Summer Olympics in Rome. However, at the 1968 Summer Olympic Games in Mexico and the Winter Olympic Games in Grenoble, France, the Soviet team came second place overall. The Moscow Spartakiad Games (1956, 1959 and 1963) mobilised a significant proportion of the Soviet sportspeople. Khrushchev's decentralisation and rationalisation programme of 1957 saw Soviet sports reorganised. The aim was to increase mass participation and make better use of the existing sports services and facilities. Furthermore, the Labour and Defence programme and physical education were revised. The newly established unionwide Sports Society instructed the Council of Trade Unions to help run

\footnotetext{
${ }^{16}$ Riordan, Sport in Soviet Society, 3.

17 Eric Hobsbawm, Age of Extremes.(London: Abacus, 1994), 496.The Marxist historian Eric Hobsbawm summarises this new materialist aspect of Soviet society: "The assent to communism of "the masses" depended not on their ideological or other convictions but on how they judged what life under communist regimes did for them, and how they compared their situation with others'.
} 
sports for the workers in each republic. (In Uzbekistan this voluntary sports society was given the name Mekhnat in urban centres and Pakhtakor in rural districts). ${ }^{18}$

Brezhnev oversaw the growth of the military-industrial complex and supported 'antiimperialist struggles' and 'wars of liberation' across the globe. To ensure the peace in the Soviet Union, he permitted the communist elites to remain in power, as long as they complied with Moscow's orders ('stability of the cadres'). During the 1970s, the government reduced spending on healthcare and social welfare; this resulted in a general decline of standards of living (zastoi, 'era of decline'). ${ }^{19}$ In terms of Soviet sport, Brezhnev continued with its expansion through financial investment and state resources. Anke Hilbrenner says:

Moreover, in the sphere of sports, Soviet society experienced unequalled development during the $1960 \mathrm{~s}$ and 1970s. The government invested millions of rubles in sports facilities, schools and infrastructure. As a result of this effort, the Soviet team dominated the Olympics from 1972 to 1980. With the 1980 Olympics scheduled to be held in Moscow, sports development took on increasing importance in the decade leading to the event. ${ }^{20}$

In 1972, the Labour and Defence programme was once again revised and placed at the centre of physical education. Timofeyev says that the plan was '... to help shape the spiritual and moral outlook of Soviet people, to encourage their physical perfection and creative endeavour'. ${ }^{21}$ During Brezhnev's tenure the Soviet elite athletes, including Central Asians, were used abroad as sporting diplomats. They were given a public relations role to win over the hearts and minds of the masses in the post-colonial and non-aligned Asian, African and South American republics. ${ }^{22}$

\section{Uzbekistan: developments, sportspeople and everyday accounts}

\section{Uzbekistan}

Uzbekistan, in 1924-25, was established under the direction of the Communist Party and intellectuals. Historically the region was predominately rural and Muslim; dynastic rulers controlled the main urban centres of Khiva, Samarkand and Bukhara. Frederick Starr's Lost Enlightenment: Central Asia's Golden Age from the Arab Conquest to Tamerlane (2015), and Edward Allworth's The Modern Uzbeks: From the Fourteenth Century to the Present (1990) explain the long and celebrated history of Central Asian societies. Uzbeks made up about 70 per cent of the population of Uzbekistan, others, for instance, Russians, Tajiks, Kazakhs, Tatars, and Karakalpaks constitute nearly 30 per cent of the total. ${ }^{23}$ Table 1 below highlights the population growth in Uzbekistan under communist rule. A growing Uzbekistan population might be useful to the Communist Party in terms of new workers; nonetheless, if the regime wished to acculturate its citizenry through sport - in conjunction with other Soviet socialisation channels - it would have to establish more sports facilities and train and employ more sports personnel to cater for the expanding and youthful population. Table 2 compares urbanisation in Russia and Uzbekistan.

\footnotetext{
${ }_{18}^{18}$ Riordan, Sport in Soviet Society, 168-170.

${ }^{19}$ Anke Hilbrenner, "Soviet Women in Sports in the Brezhnev Years," in Euphoria and Exhaustion: Modern Sport in Soviet Culture and Society, ed. Nikolaus Katzer (Frankfurt: CampusVerlag, 2010), 297-98.

${ }^{20}$ Hilbrenner, "Soviet Women in Sports in the Brezhnev Years," 298.

${ }^{21}$ Timofeyev, Soviet Sport, 33.

${ }^{22}$ Tegan Carpenter, "Development of Soviet Sport and the Components which Ensured its Success," in Sports and Coaching: Pasts and Futures, ed. Dave Day (Manchester: Manchester Metropolitan University, 2012), 85-104.

${ }^{23}$ Sevket Akyildiz, "Soviet Physical Culture in Uzbekistan: Implementation and Social Impact," in Sports and Coaching: Pasts and Futures, ed. Dave Day (Manchester: Manchester Metropolitan University, 2012), 108.
} 
Table 1 Uzbekistan population growth under the Soviet Union

Year

1926

1939

1959

1970

1979

1985

\section{Population: million people}

4.6

6.3

8.1

11.8

15.4

18.0

Source: Population of the USSR (Moscow, 1973), 14-25; Population of the USSR: Data from the 1979 All-Union Census (Moscow, 1980), pp. 4-11; Economy of the USSR in 1984

(Moscow, 1985) in Viktor Kozlov, The Peoples of the Soviet Union. (Bloomington: Indiana University Press, 1988), 47.

Table 2 Uzbekistan and Russia: proportion of urban population by percent

$\begin{array}{lllllll} & \mathbf{1 9 1 3} & \mathbf{1 9 3 9} & \mathbf{1 9 5 9} & \mathbf{1 9 7 0} & \mathbf{1 9 7 9} & \mathbf{1 9 8 5} \\ \text { Russia } & 17 & 33 & 52 & 62 & 69 & 73 \\ \text { Uzbekistan } & 24 & 23 & 34 & 37 & 41 & 42\end{array}$

Source: Naselenie SSSR, 1973, 10-13; Naradnoe khozaistvo v 1978g (Moscow, 1979), 12-13, in Kozlov, The Peoples of the Soviet Union, 51.

In the context of our analysis, before the seizure of the area by the Bolsheviks, the Russian colonial administration (1858-1917) had no sports-related policy for the Central Asians, and no sports societies existed (except for upper- and middle-class Russian settlers). Most Central Asians did not participate in modern sports except as spectators. The 1917 Revolution changed the sports landscape, and both Lenin and Stalin actively promoted a modern sports culture for mass leisure purposes and as an integrative mechanism across the Soviet Union. These two communist leaders, as early as the mid-1920s, started the implementation of contemporary physical culture in urban Uzbekistan.

About our research questions, we will begin with a description of the sports infrastructure available in Tashkent under Khrushchev. It will provide us with a framework in which to assess the scale of the built sports environment in the Uzbek capital at the moment of Brezhnev's inauguration in 1964. It shows how Moscow used modern sports culture to influence the urban dwellers' leisure time. Following on we explore the 1960s and 1970s under Brezhnev, in particular, the increasing numbers of citizens of rural and urban Uzbekistan involved in sport and sports societies (both the amateur and elite athletes). The section on women's participation in sports discusses the advances made. The last section traces the elite athletes and everyday sportspeople. To enrich our understanding of the topic, we have added the recollections of our respondents (the ordinary Soviet sportspeople, both students and adults). 
Tashkent, 1953 to 1964

Following the Second World War, development in the modern sports received investment from the Communist Party, and this continued to be the case under Khrushchev. During his leadership, in Tashkent, the urban built environment of sports was further expanded. The Pakhtakor F.C. Stadium was built in 1955-56 and hosted all of the top Russian and Ukrainian football teams. The Soviet publication, Cultural Establishments of Tashkent (1958) says approximately 80,000 Tashkent citizens were members of sports clubs and trained regularly. They had access to nine stadiums, 62 gymnasiums, and seven swimming pools. ${ }^{24}$ The main sports stadiums in Tashkent were named Dynamo, Spartak (Spartacus), and the Polytechnic. Krasnoe Znamia Stadium was in Fizkulturnaya Street (Physical Culture Street) ${ }^{25}$ Furthermore, the large state factories and farms operated sports societies and clubs designed to promote sports-for-all. The foundations of this development were laid by Stalin; he also started the weekday early morning exercise classes for factory workers (production exercises).

Also, sports boarding schools provided excellence in coaching, and for trial purposes, the first Soviet sports boarding school opened in Tashkent in 1962. It replicated the sports boarding schools built in East Germany, circa 1949. It was here that the unionwide curriculum, physical education, coaching, sports psychology, and diet and health care, were taught. Students arrived aged seven to 12, and at age 18 they graduated. (By 1980, four sports boarding schools existed in Uzbekistan, more than in most Soviet republics. $)^{26}$ The Tashkent school was well equipped and offered students -

HISTORY

STUDIES

43

Volume 12

Issue 1

February

2020

... soccer, swimming, athletics and gymnastics; the school grounds cover an area of 20 hectares,

and included a 3-hall wing for gymnastics, indoor and outdoor swimming pools, and an indoor

running track. ${ }^{27}$

\section{Brezhnev and rural and urban sportspeople}

Brezhnev's appointment as the new leader in 1964, happened at a moment when the regime was facing dilemmas with its central state planning. One example was the developmental gap between the town and country (where the majority of the population resided). In the Soviet Union sport played a vital role in the socialisation of young people and the promotion of an urban lifestyle. The success of this task required an increasing number of young citizens to take-up sports; this was easier in modern towns and cities than in the countryside. In fact, throughout the seven decades of communist rule, there was always a noticeable difference in the provision of modern sports found in the rural and urban regions of the Soviet Union. In 1960s Uzbekistan development was transforming urban living; in contrast, in the rural towns' sports facilities and coaching-staff remained inadequate, and one 1964 Soviet report says 'that only 5-6 per cent of the rural young people went in for sport on any regular basis'. ${ }^{28}$ It was significant because Uzbekistan had a growing population (as noted in Table 1).To cater for demand, by 1970, approximately 4,000 qualified sports instructors worked in Uzbekistan, and a

${ }^{24}$ Cultural Establishments of Tashkent: A Brief Reference Book on Theatrical, Scientific and Cultural Instructive Establishments. (Uzbek SSR: Goslitizdat, 1958), 181-4; the address of the Uzbekistan Institute of Physical Culture was UI, Achunbabaeva 6, 1-a Tashkent, Uzbek SSR.

${ }^{25}$ Rafis Abazov, Culture and Customs of the Central Asian Republics. (Westport, Connecticut: Greenwood, 2007), 248.

${ }^{26}$ Riordan, Sport in Soviet Society, 341.

${ }^{27}$ Fizkul'tura i sport no. 7 (1968): 5, cited in Riordan, Sport in Soviet Society, 342.

28 A. Abdumalikov and Y.S. Sholomitsky, "Nekotoryeputivnedreniyafizichcskoikul'turyisportasredisel'skikhtruzhenikovUzbekskoi SSR," cited in Y.V. Borisov, Planirovanie razvitiya fizicheskoi kul'tury i sporta sredi sel'skovo naseleniya (Moscow, 1964), 85, in Riordan, Sport in Soviet Society, 304.

\section{History Studies}


State Institute of Physical Culture was functioning in Tashkent, with further physical culture offices established in the large towns of Andijan and Bukhara. More than 30 local physical education departments were open in higher educational institutes. ${ }^{29}$

The numbers of sportspeople noted in Table 3 below reflect the expansion of the sports system, the growth in the total human population, and the new ways of calculating the people regularly involved in sport. For instance, Khrushchev's reorganisation of the mass ranking system in 1957 awarded a sports skills-based recognition or rank to many citizens. ${ }^{30}$ Soviet sources report that by the mid-1960s the official number of participating sportspeople, at all grades of the Labour and Defence programme, was in the many tens of thousands in both the urban and rural environments. The urban sports society had approximately 138,089 members, while its rural counterpart had almost 418,967 members. Furthermore, we need to consider that the Soviet planners operated within the framework of set quotas, so the figures reported by the Tashkent based managers and cadres to Moscow might have been falsified to please the authorities. Still, the information presented below shows the breadth of Soviet sports culture in general.

Table 3 A comparison of urban and rural sports societies in Kazakhstan, Uzbekistan, Georgia, and Tajikistan: the year 1966.

\begin{tabular}{|c|c|c|c|c|}
\hline $\begin{array}{c}\text { Sports club } \\
\text { name }\end{array}$ & $\begin{array}{c}\text { Number } \\
\text { of } \\
\text { collectives }\end{array}$ & $\begin{array}{c}\text { Number of } \\
\text { sportspeople }\end{array}$ & $\begin{array}{c}\text { Labour\&Defence } \\
\text { First Rank } \\
\text { sports-men }\end{array}$ & $\begin{array}{c}\text { Labour\&Defence } \\
\text { Master of Sports }\end{array}$ \\
\hline $\begin{array}{c}\text { Embak, } \\
\text { Kazakhstan } \\
\text { (urban) }\end{array}$ & 556 & 308,499 & 3,456 & 241 \\
\hline $\begin{array}{c}\text { Kairat, } \\
\text { Kazakhstan } \\
\text { (rural) }\end{array}$ & 2,988 & 659,872 & 1,567 & 82 \\
\hline $\begin{array}{c}\text { Mekhnat, } \\
\text { Uzbekistan } \\
\text { (urban) }\end{array}$ & 323 & 138,089 & 2,223 & 28 \\
\hline $\begin{array}{c}\text { Pakhtakor, } \\
\text { Uzbekistan, } \\
\text { (rural) }\end{array}$ & 1,720 & 418,967 & 848 & 344 \\
\hline $\begin{array}{c}\text { Gantiadi, } \\
\text { Georgia } \\
\text { (urban) }\end{array}$ & 747 & 149,147 & 2,825 & 287 \\
\hline
\end{tabular}

\footnotetext{
${ }^{29}$ Riordan, Sport in Soviet Society, 308.

${ }^{30}$ Ibid., 172.
} 
Şevket Ayyıldız

\begin{tabular}{|c|c|c|c|c|}
\hline $\begin{array}{c}\text { Kolmeurne } \\
\text { Georgia } \\
\text { (rural) }\end{array}$ & 1,853 & 263,418 & 1,583 & 240 \\
\hline $\begin{array}{c}\text { Tadzhikistan, } \\
\text { Tajikistan } \\
\text { (urban) }\end{array}$ & 272 & 91,998 & 724 & 82 \\
\hline $\begin{array}{c}\text { Khosilot, } \\
\text { Tajikistan } \\
\text { (rural) }\end{array}$ & 411 & 94,353 & 128 & 23 \\
\hline
\end{tabular}

Source: Voluntary Sports Societies (VSS) by membership and distinctions: 1966, cited in Riordan, Sport in Soviet Society, 418.

The built environment of sports, from the gymnasiums to the Komsomol sports clubs, were organised and run to influence the values and behaviour of the sportspeople. Table 3 shows that during the 1960s increasing numbers of urban youths and adults were involved. In light of this, Respondent 8, a male Turkmen from Turkmenistan aged 53 (an expatriate and education worker), discusses his nostalgia for Brezhnev era sports culture. In particular, he emphasised

HISTORY

STUDIES

45

Volume 12

Issue 1

February

2020 the planned nature of sports events, and how students were encouraged to participate in the civic ceremonies, street parades, and festivals:

Back in the days of the Soviet Union, all of us school children participated in many sports; in fact, the Communist Party and youth organisations encouraged us to join sports teams. In my town, we would organise festivals and sports events with red flags and processions of young people and athletes. We would all line-up and march together. We were young, and the games were fun; we enjoyed playing football and visiting leisure clubs to socialise and cheer on the athletes. ${ }^{31}$

In terms of a comparative sports ranking among the Soviet nations, Uzbekistan proved reasonably integrated into the Soviet sports system. We have indicated above that Soviet development was not uniform, the European Soviet cities were more developed than the Central Asian cities, so, proportionally more European Soviet citizens had access to modern sports. Nevertheless, by 1972 Uzbekistan was classified as a middle-ranking sports republic: Georgia, Belorussia, Ukraine, and Russia had 190 or more participants per 1,000 people; Turkmenistan, Kazakhstan, Kyrgyzstan, Uzbekistan, and Estonia had 160 to 180 participants per 1,000 people, while Azerbaijan, Lithuania and Latvia had between 129 and 145 participants per 1,000 people'. Armenia and Tajikistan had fewest sports participants. ${ }^{32}$

The Soviet military promoted modern sport; however, this institution functioned separately from the Committee on Physical Culture and Sport. The Volunteer Society for Cooperation with the Army, Aviation, and Navy (DOSAAF, established in 1923) was a paramilitary organisation that promoted military-patriotic education and sports in schools, colleges, and the Komsomol. It aimed to prepare young men for universal military service as conscripts and professionals. It involved learning military-related sports like rifle shooting, parachuting, and hiking. The DOSAAF's military-sportspeople assisted with: '... the paramilitary "Zarnitsa" [Summer

\footnotetext{
${ }^{31}$ Unstructured interview with Respondent 8, June 2011. Author's personal archive.

32 Narodnoye khozyaistvo SSSR, 1922-1972, Moscow, 1972, 9, and Sport v SSSR no. 12 (1972), 7-13, cited in Riordan, Sport in Soviet Society, 307.
} 
Lightning] and "Orlenok" [Eaglet] games for school children, and in the competitions for the best organization of mass sports work in the schools and vocational-technical schools, ${ }^{33}$ The book DOSAAF Training in Uzbekistan (1979) reports that: 'The DOSAAF organization of Uzbekistan is one of the detachments of this society' ${ }^{34}$ The Soviet Union's defence strategy had the eighteen-year-old men conscripted for a duration of military service. The DOSAAF members in Uzbekistan were useful for Moscow because a steady supply of physically fit male conscripts could assist in the Soviet-Afghan War of 1979 to 1989 . We need to recall here that Uzbekistan shares a border with Afghanistan and this would make the deployment of Uzbek conscripts in the campaign a practical solution.

Respondents 12 and 13, both ethnic Tajik men from Tajikistan aged 50 and 52 respectively (both expatriates and education workers), explained that modern sports were popular in their urban college days. They affirmed that the Soviet military had its own sports facilities for DOSAAF members. Respondent 12 comments on the accessibility of modern sports in the cities and the role of the DOSAAF in his youth upbringing:

During the Soviet Union days, the sport was part of our growing up. I was sent by my parents to a city school and therefore moved away from my countryside home; there I stayed with my aunt and uncle in the big city. Everything was modern there, at school and college, we regularly played sports. There was so much more to do there than back in my small town. As a teenager, I played sports during my voluntary military service. The military used physical activities to make us fitter and stronger. The army provided the gymnasiums and trainers. It appealed to young men looking for social identity. Physical culture was very much part of our lives back then, both in the schools and in the DOSAAF. The Communist Party supported sport in society, and together with friends we regularly played football and visited the sports centre. ${ }^{35}$

Women and sport

By the 1960s, female athletes had become part of the social fabric in Uzbekistan's cities, but, many rural Uzbek parents still forbade their daughters from wearing skin-tight sports costumes. In 1964, a Soviet Uzbek writer said:

We need to propagandise the importance of sport among women, and physical education establishments should train more specialists from among local girls who would themselves have a hand in training good sportswomen. ${ }^{36}$

Gradually changes occurred in Uzbekistan, between 1959 and 1969 the number of women participating in sports increased, rising from approximately 3.6 per cent to 10.8 per cent of their amount (in Ukraine circa 1968 Ukrainian women constituted 34.2 per cent). ${ }^{37}$ In 1968, in Dushanbe, Kyrgyzstan, the First Women's Youth Central Asian and Kazakh Spartakiad was held. ${ }^{38}$ The First Spartakiad for Rural Women of Uzbekistan occurred in 1969 with 300 finalists

\footnotetext{
${ }^{33}$ Ibid.

${ }^{34}$ A. Khodzhibayev, To New Heights: DOSAAF Training in Uzbekistan, Moscow, 1979, 5, cited in USSR Report (31 March 1980) USSR Report, 9006 Military Affairs, 12, Foreign Broadcast Information Service, U.S.: https://www.cia.gov/library/readingroom/document/cia-rdp82-00850r000200060047-2 (Date Accessed 1 March 2019). The source says of the DOSAAF: 'In its ranks are more than 5 million persons who are members of 20,000 primary organizations.'

${ }^{35}$ Unstructured interview with Respondent 12, July 2012. Author's personal archive.

${ }^{36}$ A. Abdumalikov and Y.S. Sholomitsky, cited in Riordan, Sport in Soviet Society, 319.

${ }^{37}$ Riordan, Sport in Soviet Society, 318.

${ }^{38}$ Timofeyev, Soviet Sport, 32.
} 
(three-quarters were ethnic Uzbeks). ${ }^{39}$ In 1970, the Chairman of the Uzbek Supreme Soviet Commission on Youth Affairs said:

... in Uzbekistan, as in other Central Asian republics, women's path to sport has been linked with a struggle against religious prejudices and for equal status in society.

I would call our first sportswomen real heroines. They accomplished real feats of valour in liberating women from the age-old yoke of religion and the feudal-bey order. ${ }^{40}$

This apparatchik was undoubtedly on the message in regards to the Soviet attitudes on women and anti-religiosity. However, by the early 1980s, it is unclear whether many rural working women had time for regular organised sports, and the Western sources do not mention that they did.

Despite Marxist-Leninist support for gender equality, there existed culturally influenced male attitudes that had continued from the pre-Revolutionary era. Respondent 2, a Kazakh woman from Kazakhstan aged 56 (expatriate and professional), was a teenage schoolgirl in the early 1980s. She mentions the survival of male patriarchy and traditional values despite the Communist Party's policies and rhetoric.

The communists changed many things that my parents and grandparents had once tolerated. However, we are talking about Central Asia, and some things change slowly. Women had access to modern sports facilities, but they also had to work on farms and factories and raise children. It was all very demanding in terms of time and energy. Often it was the men who played sports. Still, some Kazakh women did become famous through sports and at the time were role-models to young women. 41

The personal likes and dislikes of individuals influenced their interaction with the Soviet sports culture. It does not infer anti-Soviet views; instead, they were selecting the elements of Soviet popular culture they most favoured. Respondent 3, an ethnic Tajik woman from Uzbekistan aged 52 (expatriate and professional) articulated her dislike of strenuous physical sports. Nevertheless, at school and college, she used the sports culture to socialise with friends and meet people:

I never did enjoy physical sports much. It was all too competitive and physically demanding. I preferred dancing and singing. Modern and folk dances were enjoyable. I liked the art galleries and watching ballet. I found dance very sociable, and I went along with my female college friends for fun. Of course, we were all unmarried then, and I was free to talk with boys at the dance hall.

The Communist Party pushed sports on us a lot and one way or the other we got involved. Some of my friends seemed more enthusiastic than me about sports. ${ }^{42}$

Respondent 15, a Lithuanian woman aged 52 (expatriate and chess tutor), discussed her involvement with the institutionalised world of Soviet sport. She explained how it had shaped her upbringing and employment options. It also allowed her to travel within the multinational Soviet Union. She describes how the regime provided the services and facilities for the younger generations. Also, her story clarifies how Soviet culture moulded life choices. In her recollection of travel and her everyday experience of the 'Muslim and Turkic cultural regions', she embodies the Soviet values of socialist internationalism and inter-ethnic communication. Furthermore, her example mirrors, if in a small way, the sports diplomacy work of the elite Soviet athletes.

\footnotetext{
${ }^{39}$ Riordan, Sport in Soviet Society, 320.

${ }^{40}$ Fizkul'tura i sport no. 6 (1970): 5, cited in Riordan, Sport in Soviet Society, 320.

${ }^{41}$ Unstructured interview with Respondent 2, August 2011. Author's personal archive.

${ }^{42}$ Unstructured interview with Respondent 3, July 2012. Author's personal archive.
} 
As a child, I was a Young Pioneer. I did not have an ear for music or dance, I have a rational mind, so I chose the chess club. I enjoyed learning chess and competing against others. Later, I became a Komsomol member and went on to study a four-year higher education course in sports coaching. Though I could have opted to specialise in sports psychology and coaching, I decided to concentrate on chess coaching. Ever since then, I have been a children's chess tutor, both in Lithuania and here in the United Kingdom. The communist political system created opportunities for us and encouraged us to participate in organised events. During the 1980s, through the university chess society, I travelled to compete in tournaments in Azerbaijan and Uzbekistan. We communicated in Russian. For me, coming from a Baltic country, it was exciting and culturally different; these were Muslim and Turkic cultural regions of the Soviet Union. The food and dress were different from my Eastern European culture. The Communist Party was attempting to change the role and status of women in that society. ${ }^{43}$

Respondent 9, an Uzbek businesswoman (aged 50) spoke to us in Tashkent, in English, about everyday life under the communists. Like many Uzbeks, she was proud of her culture and society, but acknowledged, if reluctantly, the influence of the former Soviet planners:

Life is good today; we can open businesses and make money. The government should help us do business. Before, in the time of the communists, life was very different. They controlled everything, like housing, education, work, and hospitals. In regards to sport? They controlled this too, including the clubs and places of sport. My husband played sports like football and ran on the sports track. Many people did. The sports were popular with men and some women too. However, women have to manage their family home and work. We do not have as much time for sport. Today, we have our Uzbek culture back; we have many sports now, just like in the West. In my business, we have a sauna, a snooker table, and table tennis for guests and friends. ${ }^{44}$

Elite athletes and the mass sportspeople

This section will discuss the role of the elite athletes and mass sportspeople in Uzbekistan under Brezhnev. The elite athletes were a problematic concept for the Communist Party and its critical views on social elitism. All through the 1960s and 1970s, Uzbekistan's athletes won medals at home and abroad for the Motherland (the Soviet Union), their nation (Uzbekistan), and themselves. These athletes show that a working relationship existed between elite sportspeople, coaches, and the communist regime, even in the less-developed Central Asia region. Also, the well-known athletes were role-models in society and assisted in generating Soviet patriotism. For instance, in August 1974, the Tashkent boxer Rufat Riskiev won his middleweight division fight at the World Boxing Championships in Havana, Cuba. ${ }^{45}$ Later he won medals at the Olympic Games and other international championships. At the 1980 Moscow Olympics, the competitors of Uzbekistan won several medals: Yuriy Kovshov won two medals, gold and silver, in equestrian events. Larisa Pavlova was awarded a gold medal as part of the Soviet volleyball team. Gold medals were also won by Olga Zubareva (handball team) and Erkin Shagaev (water polo), while Rustam Yambulatov (shooting) won a silver medal. $^{46}$

\footnotetext{
${ }^{43}$ Unstructured interview with Respondent 15, May 2019. Author's personal archive.

${ }^{44}$ Unstructured interview with Respondent 9, April 2009. Author's personal archive.

${ }^{45}$ Timofeyev, Soviet Sport, 34.

${ }^{46}$ See Sevket Akyildiz, "Olympic Culture in Soviet Uzbekistan 1951-1991: International Prestige and Local Heroes" Polyvocia: The SOAS Journal of Graduate Research, 3, (March 2011): 1-16 http://www.soas.ac.uk/research/rsa/journalofgraduateresearch/edition-3/file67219.pdf (Date Accessed 28 June 2015); see also Sevket Akyildiz, "Soviet Physical Culture in Uzbekistan: Implementation and Social Impact," 105122; and Sevket H. Akyildiz, “Assessing Uzbekistan's Olympic Performance, 1992-2012"Central Eurasian Scholars and Media Initiative(2012):http://cesmi.info/wp/?p=202, or http://www.bbc.com/kyrgyz/in depth/2012/08/120827 sevket hilton take on.shtml,
} 
Notwithstanding, the condition of the ordinary citizen contrasted with the funding of elite athletes. The latter group received a disproportionate amount of the available government funding. The money issue made a mockery of the sport-for-all policy. The problem with Soviet sport had always been inadequate central funding and the inefficient management at the local level by officials. The liberal-capitalist Western countries generally had more and better sports facilities and services available to its citizens than any communist society. ${ }^{47}$ So, despite 60 years of the Soviet sport and its popularity and everyday use in social interactions, further planning was necessary. To reinforce a point made above, the youth upbringing through modern sport was not uniform across the country, because the rural secondary schools lacked suitable coaches, playing fields and gymnasiums, and this curtailed the sports-related upbringing (Uzbekistan being one example). 'The practical side did not look quite as sparkling as statistics or theory. Many republics had major problems in building up a working sport system due to lack of necessary materials,' says Evelyn Mertin. ${ }^{48}$ In the context of the early 1980 s, Riordan discusses this unionwide development problem:

A Soviet education minister has admitted that as many as 80 per cent of all Soviet secondary schools have no sports grounds, 75 per cent have no gyms and 50 per cent do not have even enough equipment for physical education lessons. ${ }^{49}$

However, Brezhnev's 1970s sports policy reforms were meant to improve the universality of physical culture in the Soviet Union. ${ }^{50}$ During the $26^{\text {th }}$ Congress of the Communist Party in 1981, Timofeyev reports that Brezhnev 'pinpointed the socio-economic, defence, cultural and

HISTORY

STUDIES

49

Volume 12

Issue 1

February

2020

educative functions of physical culture. ${ }^{51}$ Brezhnev questioned the appropriateness of the existing physical culture system and acknowledged its key deficiencies:

Concern for people's health is inseparable from the development of physical culture and sport.

The Moscow Olympics strikingly showed the remarkable achievements of Soviet athletes.

However, we have always been interested not only in athletic achievements but also, and above

all, in giving physical culture and sport a mass character. The advances in this sphere are selfevident. Nonetheless, for most people, sport is still only a spectacle. This situation should be corrected. Physical culture should be part of the everyday life of large segments of the population, particularly children. ${ }^{52}$

Respondent 1, an ethnic Uzbek woman aged 42 (cultural worker) spoke with us in a gift shop in Samarkand and recalled the days when the Soviet Union athletes were a major presence in the global media. She remarks that the communist regime made her feel a sense of pride in her republic and the Soviet Union.

The top athletes made us feel good about our republic and the Soviet Union. My family listened to the sporting successes on the radio. My father and brothers would read the sports newspapers and magazines at home. In the early 1980s, our neighbour bought a television set, and our families would gather to watch the major sports events and cheer on our heroes. I was a student, and we all knew the names of the famous Soviet athletes and our teachers would discuss them in class. We had some talented gymnasts and footballers and watching them made us feel happy and

orhttp://www.bbc.com/uzbek/institutional/2012/08/120824 cy uzbek shevket akyildiz.shtml (Date Accessed 28

June 2015).

${ }^{47}$ Riordan, Soviet Sport: Background to the Olympics, 16.

${ }^{48}$ Evelyn Mertin, "Ethnic Minorities and National Identity in Soviet Sport," Studies in Physical Culture and Tourism 15:3 (2008): 165-70, 5.

${ }^{49}$ Riordan, Soviet Sport: Background to the Olympics, 16.

${ }^{50}$ Archie Brown and Michael Kaser and Gerald Smith, The Cambridge Encyclopedia of Russia and the former

Soviet Union. (Cambridge: Cambridge University Press, 1994), 499; Riordan, Sport in Soviet Society, 295-35.

${ }^{51}$ Timofeyev, Soviet Sport,36.

${ }^{52}$ Brezhnev, Report of the Central Committee, 81-2. 

share. $^{53}$

Respondent 5, an Uzbek woman from Uzbekistan aged 52 (an expatriate and education worker) explained that for her the modern sports were family entertainment, and they watched on television the mega-events like the Summer Olympic Games and similar domestic sports events in Moscow. This home viewing, circa the 1980s, of the televised sport, was something very different from Stalin's notion of mass mobilisation of the citizenry through organised leisure. Stalin's model had involved the observation and surveillance of mass behaviour at stadiums and in sports-themed street parades. Our Uzbek respondent 5 said:

My family had a flat in the centre of Tashkent, and my father worked for the local government. Living in the city meant we had access to Soviet culture. We had access to education, the arts, and sports clubs. In my family, there was much excitement about the significant sports events, and we would talk at dinner about the upcoming gymnastics and athletics championships. We had a television, so watching sport was a family activity, and sport was a topic we discussed with friends at college. We knew about the successes of Soviet athletes performing in the Western countries and at the Olympic Games. As spectators, we found it very entertaining, and somehow, it seemed to draw us in. ${ }^{54}$

\section{Conclusion}

\section{Soviet Union}

The Soviet culture was part of a project to modernise and develop the urban and rural Russia and Central Asia. It was also designed to socialise and acculturate the workers, peasants, and intellectuals of the post-1917 Revolutionary society. The aim was to transform the values, attitudes, and behaviour of the masses and integrate them into the new society. The task faced by the Communist Party was considerable, not least because the 1920s Soviet Union - the world's first socialist and multinational society - was chiefly an agricultural and illiterate society.

One strand of the new Soviet culture was physical culture (and sport). Lenin had approved of centrally planned leisure and recreation for children and adults, and he foresaw a role for sport in the mass mobilisation of citizens and entertainment purposes. Sport also had a role in improving mass health, and in Soviet nation-state building. However, it was Stalin, during the 1930s and 1940s, who began the unionwide physical culture. Stalin institutionalised Soviet physical culture and established many of the core sports policies. It was done to hasten sociocultural integration and to deepen and broaden Soviet culture in society. The people's participation in Soviet sport was a citizenship right and duty. The Soviet cities and large towns benefitted most from this sports model. The Soviet sports culture also created new social identities for people who faced the Sovietisation of their society. It allowed (young and procommunist) citizens to partake in Soviet culture and have fun. From the mid-1930s onwards, propaganda slogans actively encouraged the population to enjoy the socialist sport as a new and better way of life. The world of planned recreation would offer other benefits like employment and career opportunities for young adults originating from modest backgrounds. The implementation of modern sport occurred through the unionwide institutions: The Committee of Physical Culture and Sport, the Labour and Defence programme, the volunteer sports societies, the DOSAAF, and the Komsomol. Through these channels, the socialisation and

\footnotetext{
${ }^{53}$ Unstructured interview with Respondent 1, April 2009. Author's personal archive.

${ }^{54}$ Unstructured interview with Respondent 5, October 2011. Author's personal archive.
} 
acculturation influenced young minds and bodies-especially those adolescents less interested in the arts, theatre, and literature.

This paper has shown that the Soviet sports under Khrushchev (1953 to 1964) and Brezhnev (1964 to 1982) were generally-speaking a continuation of the Stalinist sports agenda. Both leaders had advanced modern sport across the urban Soviet Union. Khrushchev's consolidation and expansion of the modern sports infrastructure, services, and personnel reflected the primary aims of Lenin and Stalin. The sports, during the Cold War, were deployed as a soft power tool in the cultural confrontation between the Soviet Bloc and the Western liberal democracies. Moscow wanted to portray the Soviet Union as a dynamic workers' society. The Soviet Union medals domination at the Olympic Games characterises this Cold War mindset. However, the Communist Party had, since Stalin, disproportionately invested state resources in the training of elite athletes for international sports championships; this was at the expense of advancing and improving the physical culture in the rural regions. Another topic noted in our paper was Khrushchev's, and Brezhnev's support for an increased materialist and consumerist lifestyle for all-this included the watching of sport on privately-owned television sets.

When Brezhnev became the leader in 1964, the Soviet sports culture had already been developing and evolving for nearly 45 years. During Brezhnev's leadership, the Labour and Defence programme underwent revision, and he spoke in support of the sport-for-all policy. Brezhnev invested in sports infrastructure and personnel to help socialise children and adults and to meet their everyday fitness needs. His tenure saw the Soviet Union dominate the Summer and Winter Olympic Games, improve the participation of Slavic and Central Asian women in sport, and encourage the Slavic and Central Asian elite athletes to become cultural ambassadors in the post-colonial Asian and African countries.

\section{Uzbekistan}

The Soviet sports project in Uzbekistan between 1917 and 1991 remained an urban phenomenon. In the cities and the large towns, the Communist Party increasingly provided the contemporary leisure and sports for both the Central Asian locals and the Russian settlers. By the 1940s, at the local and regional levels, sports societies, clubs, and teams were operational. The propaganda spoke of 'civilisation versus backwardness' and 'enlightenment triumphing over traditionalism'. The talented young athletes, often from humble backgrounds, were spotted and given the opportunities to progress in life. They would train with Russian and Central Asian sports instructors and coaches at the newly available higher education sports departments. The communists pushed ahead with social transformation, and as early as 1952 an Uzbek female gymnast had won a gold medal for the Soviet Union at their first Summer Olympic Games.

In Tashkent, under Khrushchev and Brezhnev, sports culture was advanced in terms of the built environment and the places of mass sport. Importantly, the sports institutions and associations, gymnasiums, stadiums, and clubhouses were inclusive. The communists, despite their morally dubious politics and neo-colonial mentality, made modern leisure affordable and inclusive for the citizenry. The Labour and Defence programme and the new facilities and services benefitted the urban Central Asians. New sports places and sites were opened in Tashkent to cater for Uzbekistan's growing and youthful population. As a result, from the 1960s onwards, both the regular sports enthusiasts and the elite athletes grew in number as did their membership of the sports societies. So, it is fair to say that under Brezhnev, the modern sports culture had become an everyday reality for urban dwellers of Central Asia. 
Nonetheless, folk sports in Uzbekistan continued to be popular, especially in the rural districts where the majority of Uzbeks resided throughout the communist rule. It was here that the provision of modern sports was inadequate. To win hearts and minds, the communists had standardised the Russian and Central Asian folk sports and incorporated them into the modern Soviet sports system. In both modern and folk sports, there might have been some social agency at play, with the ordinary sportsperson finding in games a distraction from the stresses of everyday work and intra-family tensions.

Our respondents spoke about the Communist Party's active promotion of modern sports. They recalled how the regime provided the resources for sport and talked about their years at school, college, and university infused by Soviet sport. The interviewees emphasised how the Communist Party organised Soviet sports events, and, significantly, they provided the necessary human resources, awards, and institutions to make it work. The oral histories documented in this work reveal to us that despite the authoritarian nature of the Soviet society, the interviewees had generally positive and nostalgic memories of the years associated with Soviet sport. Indeed, they expressed themselves in terms of general satisfaction with Brezhnev's version of Soviet sport. Some of them spoke candidly about their involvement with local sports festivals and parades. They also recalled how, as spectators, they viewed athletics, football, and gymnastics in sports arenas, and on television at home. Consequently, the oral history accounts of the Soviet past help us understand a little better how and why modern sport and leisure was popular.

Our interviewees acknowledge that the organised Soviet world of sport had been an ideological tool and a constructed lifestyle. They are aware it was intended to make them healthier and to make them satisfied both psychologically and socially with life under the communists. Living in a closed social system with minimal liberties, they had few options but to participate in and absorb the Soviet culture. The modern sport brought young people together and fostered in them a sense of belonging and togetherness, and it enabled people from different social and ethnic communities to meet. In terms of nation-building and Soviet identification, during Brezhnev's leadership, Uzbekistan was one majority-Turkic and Muslim society within the Soviet Union that was able to compete in top-level sports on a more or less equal footing with the Slavic Soviet republics and the Western capitalist countries alike.

However, all of our interviewees voiced their active support for the national sovereignty and independence of their post-Soviet republics. After seven decades of the colonial-style rule from Moscow, they said they were now considerably freer to create their national laws and society and, notably, to rediscover their marginalised cultural heritage and Islam. These facets of their individual and national identities are essential to all Central Asians in self-defining who they are and the values and lifestyles they wish to pursue. Indeed, the Soviet modernity and cultural management planning had suppressed some of the core elements of native culture. Despite this profound sense of loss, other aspects of the Soviet past left a different legacy, for instance, modern sports are now very much part of everyday life for Central Asians.

\section{Bibliography}

Cultural Establishments of Tashkent: A Brief Reference Book on Theatrical, Scientific and Cultural Instructive Establishments. Uzbek SSR: Goslitizdat, 1958.

ABAZOV, Rafis. Culture and Customs of the Central Asian Republics. Westport, Connecticut: Greenwood, 2007.

AKINER, Shirin. Central Asia: New Arc of Crisis? London: Whitehall Paper Series, 1993. 
AKYILDIZ, Sevket, "Soviet Physical Culture in Uzbekistan: Implementation and Social Impact", in Sports and Coaching: Pasts and Futures, ed. Dave Day. Manchester: Manchester Metropolitan University, 2012, 105-122.

AKYILDIZ, Sevket, "Olympic Culture in Soviet Uzbekistan 1951-1991: International Prestige and Local Heroes" Polyvocia: The SOAS Journal of Graduate Research, 3, (March 2011): 1-16.http://www.soas.ac.uk/research/rsa/journalofgraduateresearch/edition3/file67219.pdf (Date Accessed: June 28, 2015).

AKYILDIZ, H. Sevket, “Assessing Uzbekistan's Olympic Performance, 1992-2012” Central Eurasian Scholars and Media Initiative (2012):http://cesmi.info/wp/?p=202, or http://www.bbc.com/kyrgyz/in_depth/2012/08/120827_sevket_hilton take_on.shtml, orhttp://www.bbc.com/uzbek/institutional/2012/08/120824 cy uzbek shevket akyildiz.

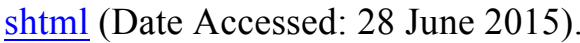

AKYILDIZ, Sevket Hylton. "Modern and Folk Sports in Central Asia under Lenin and Stalin: Uzbekistan from 1925 to 1952." Vakanuvis-International Journal of Historical Researches 4:2 (Fall 2019): 515-541.

BREZHNEV, L.I. Report of the Central Committee of the CPSU. Moscow: Novosti Press Agency Publishing House, 1981.

BROWN, Archie, and Michael Kaser and Gerald Smith. The Cambridge Encyclopedia of Russia and the former Soviet Union. Cambridge: Cambridge University Press, 1994.

HISTORY

STUDIES

53

Volume 12

Issue 1

February

2020

DADABAEV, Timur. "Trauma and Public Memory in Central Asia: Public responses to political violence of the state policies in Stalinist Era in Uzbekistan and Kyrgyzstan." Kyoto Bulletin of Islamic Area Studies 3:1 (July 2009): 108-138.

CARPENTER, Tegan, "Development of Soviet Sport and the Components which Ensured its Success," in Sports and Coaching: Pasts and Futures, ed. Dave Day. Manchester: Manchester Metropolitan University, 2012, 85-104.

FIGES, Orlando. The Whisperers: Private Life in Stalin's Russia. London: Penguin, 2008.

GRANT, Susan. Physical Culture and Sport in Soviet Society: Propaganda, Acculturation, and Transformation in the 1920s and 1930s. London: Routledge, 2013.

HILBRENNER, Anke, "Soviet Women in Sports in the Brezhnev Years," in Euphoria and Exhaustion: Modern Sport in Soviet Culture and Society, ed. Nikolaus Katzer. Frankfurt: CampusVerlag, 2010, 297-98.

HOBSBAWM, Eric. Age of Extremes. London: Abacus, 1994.

KATZER, Nikolaus, and Sandra Budy and Alexandra Kohring and Manfred Zeller. Euphoria and Exhaustion: Modern Sport in Soviet Culture and Society. Frankfurt: CampusVerlag, 2010.

KHODZHIBAYEV, A., To New Heights: DOSAAF Training in Uzbekistan, Moscow, 1979, 5, cited in USSR Report (31 March 1980) USSR Report, 9006 Military Affairs, 12, Foreign Broadcast Information Service, U.S.:https://www.cia.gov/library/readingroom/document/cia-rdp8200850r000200060047-2 (Date Accessed: 1 March 2019).

KOZLOV, Viktor. The Peoples of the Soviet Union. Bloomington: Indiana University Press, 1988. 
MERTIN, Evelyn, "Ethnic Minorities and National Identity in Soviet Sport." Studies in Physical Culture and Tourism 15:3 (2008): 165-70.

RICHARDS, Michael. "From war culture to civil society: Francoism, social change, and memories of the Spanish Civil War." History and Memory 14:1 Special Issue: Spanish Memories: Images of a Contested Past (2002): 93-120, 93.

RIORDAN, James. Sport in Soviet Society: Development of Sport and Physical Education in Russia and the USSR. Cambridge: Cambridge University Press, 1980.

RIORDAN, James. Soviet Sport: Background to the Olympics. New York: Washington Mews Books, 1980.

RYWKIN, Michael. Moscow's Muslim Challenge: Soviet Central Asia. Armonk, New York: M. E. Sharpe, 1990.

TIMOFEYEV, A, and Kopytkin, Y. Soviet Sport: The Success Story. Moscow: Raduga Publishers, 1987. 